\title{
What's new in an old-fashioned journal of histochemistry?
}

\author{
M. Biggiogera \\ Dipartimento di Biologia Animale, University of Pavia, Italy
}

Scientific journals experience, in these last years, a series of changes which will probably radically modify the aspect of the scientific literature as we have known it till now. From printed pages, the Journals are shifting toward online printing, new journals are appearing only in this form and have high impact factors; traditional, established journals have difficulties in making a living. Moreover, there is a constant drift toward new scientific trends which progressively modifies the journals themselves.

In this view, the publications devoted to histochemistry and cytochemistry are representative.

Almost all the journals in this field have slowly but steadily shifted from the description of methods and techniques to their application for solving problems in cell biology. This trend has been general, and has involved the journals of histochemistry in the United States and Europe as well.

In fact, recently also the European Journal of Histochemistry has modified its title by adding the subtitle A journal of functional cytology to emphasize the pivotal role of histochemistry in the understanding of the basic mechanisms underlying major biological processes such as differentiation and the regulation of normal and tumor cell growth (as reported in the Editors' forewords of the first issue of volume 50,2006). At this subject, it is interesting to look at the papers on cell biology recently published herein, and review articles are the best introduction to this field.

In the three-parted review by Thomas Cremer and Christoph Cremer (2006 a, b), the ambitious project of the history of chromosome territories is perfectly fulfilled. This concept, nowadays widely accepted, had ups and downs in its history, facing phases of rise, fall and resurrection. The present understanding of the nucleus is actually based on it, and its implications for nuclear structure and function are still far from having been fully explored.

Nuclear proteins and their involvement in chromatin arrangement seem to be one of the keys to laminopathies: Maraldi et al. (2006) point to one of these proteins, emerin (see also Squarzoni et al.,
2005), as directly involved in these pathologies. Small molecules recognized since a few years as capable of intranuclear signal transduction (Evangelisti et al. 2006) as well as cdks and cyclins in muscle differentiation (De Falco and De Luca, 2006) are the topics of other articles. On still nuclear background, Segui-Simarro et al. (2006) analysed the presence of Cajal bodies and their increase in relation to embryogenic development in microspores, thus confirming the conservation during evolution of basic nuclear mechanisms in animals and plants. Nuclear functions are dynamic, and the behaviour of organelles as well (see Soldani et al., 2006; Smetana et al., 2006). The timedependent expression of different proteins is described and applied also to pathology (see for instance Sereno et al., 2006) with p53, Bcl-2 and other markers, such as the musclebind-like protein for myotonic dystrophies (Cardani et al. 2006). Interestingly, a strictly dynamic phenomenon such as differentiation often includes in its course a series of events common to cell death: Sjakste and Sjakste (2007) have shown that DNA strand breaks present in differentiating cells may derive from a non-apoptotic function of caspases. Apoptosis, in its turn, may be induced by inhibition of the proteasome, at least in an in vitro system (Sassone et al. 2006).

In between the above quoted papers, however, we can find in the European Journal of Histochemistry several more technical articles, devoted to set up new techniques or to describe the side effects of the application of well known methods, like the use of restriction endonucleases ( $\mathrm{Nieddu}$ et al. 2006) or the simultaneous application of two techniques (i.e., the mmunogold silver staining and epi-fluorescence) which are rarely used together (Helliot et al. 2007). Vitolo et al. (2005) have used an anti DNA ligase I antibody to label proliferating cells in culture and tissue sections; Sarasquete and Gutierrez (2005) proposed a new tetrachromic technique for studying normal and pathological tissues; Edqvist et al. (2006) identified retinal subtypes by localising transcription factors. 
When considering the scientific articles published in traditional histochemical journals such as the European Journal of Histochemistry one is always surprised by the sometimes apparent scientific heterogeneity of papers which appear in the same issue. We can find, for instance, a report on the stimulation of osteoblast growth by electromagnetic field (Icaro Cornaglia et al., 2006) or the gossypol spermatotoxicity (Akinola et al., 2006) or phagosome maturation in Paramecium (Wyroba et al. 2007). These unrelated papers make use of histochemistry in its broadest sense, thus testifying the vitality of this area. This is also apparent in the papers collected in memory of Carlo Rizzoli in the first supplement to volume 51 (2007) which point out how the Fathers of the Italian Histology valued histochemistry as an almost unique and irreplaceable approach. The articles by Osculati et al. (2007) or Formigli and co-workers (2007) are good examples of this. And it is worth mentioning also the paper by Sirigu et al., (2006) on the prognostic prediction on the outcome of cutaneous melanoma. In this paper, histochemistry is not only a tool but a bridge linking two populations from different country like Ecuador and Italy.

One may conclude that traditional cytochemical approaches presented in a conventionally published journal still keep their informational impact on cell biology while the printed micrographs preserve their aesthetic charm.

As Lord Byron wrote: One drop of ink makes thousands, perhaps millions, think.

\section{References}

Akinola OB, Dosunmu 00, Dini L, Ajayi S. I Proteinaceous diet inhibits gossypol-induced spermatotoxicity. Eur J Histochem 2006; 50:205-8.

Cardani R, Mancinelli E, Rotondo G, Sansone V, Meola G. Muscleblindlike protein 1 nuclear sequestration is a molecular pathology marker of DM1 and DM2. Eur J Histochem 2006; 50:177-82.

Cremer T, Creme C. Rise, fall and resurrection of chromosome territories: a historical perspective. Part I. The rise of chromosome territories. Eur J Histochem 2006a; 50:161-76.

Cremer $\mathrm{T}$, Cremer $\mathrm{C}$. Rise, fall and resurrection of chromosome territories: a historical perspective. Part II. Fall and resurrection of chromosome territories during the 1950s to 1980s. Part III. Chromosome territories and the functional nuclear architecture: experiments and models from the 1990s to the present. Eur J Histochem 2006b; 50:223-272.

De Falco M, De Luca A. Involvement of cdks and cyclins in muscle differentiation. Eur J Histochem 2006; 50:19-24.

Edqvist PH, Myers SM, Hallbook F. Early identification of retinal subtypes in the developing, pre-laminated chick retina using the transcription factors Prox1, Lim1, Ap2alpha, Pax6, Isl1, Isl2, Lim3 and Chx10. Eur J Histochem 2006; 50:147-54.

Evangelisti C, Bortul R, Tabellini G, Papa V, Cocco L, Martelli AM. Nuclear expression of diacylglycerol kinases: possible involvement in
DNA replication. Eur J Histochem 2006; 50:9-13.

Formigli L, Meacci E, Zecchi-Orlandini S, Orlandini GE. Cytoskeletal reorganization in skeletal muscle differentiation: from cell morphology to gene expression. Eur J Histochem 2007; suppl 1: 21-8.

Helliot B, Panis B, Busogoro JP, Sobry S, Poumay Y, Raes M, et al. Immunogold silver staining associated with epi-fluorescence for cucumber mosaic virus localisation on semi-thin sections of banana tissues. Eur J Histochem 2007; 51:153-8.

Icaro Cornaglia A, Casasco M, Riva F, Farina A, Fassina L, Visai L, et al. Stimulation of osteoblast growth by an electromagnetic field in a model of bone-like construct. Eur J Histochem 2006; 50:199-204.

Maraldi NM, Lattanzi G, Capanni C, Columbaro M, Merlini L, Mattioli $\mathrm{E}$, et al. Nuclear envelope proteins and chromatin arrangement: a pathogenic mechanism for laminopathies. Eur J Histochem 2006; 50:1-8.

Nieddu M, Pichiri G, Manconi S, Mezzanotte R. Some remarks on the use of TaqI to detect highly repetitive DNA sequences in human chromosomes. Eur J Histochem 2006; 50:281-3.

Osculati F, Bentivoglio M, Castellucci M, Cinti S, Zancanaro C, Sbarbati $A$. The solitary chemosensory cells and the diffuse chemosensory system of the airway. Eur J Histochem 2007; 51 Suppl 1:65-72

Sarasquete C, Gutierrez M. New tetrachromic VOF stain (Type III-G.S) for normal and pathological fish tissues. Eur J Histochem 2005; 49:211-27.

Sassone J, Ciammola A, Tiloca C, Glionna M, Meola G, Mancinelli E, et al. Apoptosis induced by proteasome inhibition in human myoblast cultures. Eur J Histochem 2006; 50:109-18.

Segui-Simarro JM, Barany I, Suarez R, Fadon B, Testillano PS, Risueno MC. Nuclear bodies domain changes with microspore reprogramming to embryogenesis. Eur J Histochem 2006; 50:35-44.

Sereno M, García-Cabezas MA, De Castro J, Cejas P, Casado Saenz E, Belda-Iniesta C, Barriuso Feijoo J, Larrauri J, Nistal M, Gonzalez Baron M. Immunohistochemical expression of p53, Bcl-2, COX-2, Cerb-B2, EPO-R, ,-catenin, and E-cadherin in non tumoral gastric mucous membrane. Eur J Histochem 2006; 50:285-92.

Sirigu P, Piras F, Minerba L, Murtas D, Maxia C, Colombari R, et al. Prognostic prediction of the immunohistochemical expression of p16 and p53 in cutaneous melanoma: a comparison of two populations from different geographical regions. Eur J Histochem 2006; 50:191-8.

Sjakste N, Sjakste T. Possible involvement of DNA strand breaks in regulation of cell differentiation. Eur J Histochem 2007; 51:81-94.

Smetana K, Klamova H, Mikulenkova D, Pluskalova M, Hrkal Z. On the nucleolar size and density in human early granulocytic progenitors, myeloblasts. Eur J Histochem 2006; 50:119-24.

Soldani C, Bottone MG, Pellicciari C, Scovassi AI. Nucleolus disassembly in mitosis and apoptosis: dynamic redistribution of phosphorylated-c-Myc, fibrillarin and Ki-67. Eur J Histochem 2006; 50:273-80.

Squarzoni S, Sabatelli P, Capanni C, Lattanzi G, Rutigliano C, Columbaro $\mathrm{M}$, et al. Emerin increase in regenerating muscle fibers. Eur J Histochem 2005; 49:355-362.

Vitolo B, Lidonnici MR, Montecucco C, Montecucco A. A new monoclonal antibody against DNA ligase $I$ is a suitable marker of cell proliferation in cultured cell and tissue section samples. Eur J Histochem 2005; 49:349-54.

Wyroba E, Surmacz L, Osinska M, Wiejak J. Phagosome maturation in unicellular eukaryote Paramecium: the presence of RILP, Rab7 and LAMP-2 homologues. Eur J Histochem 2007; 51:163-72.

Marco Biggiogera

Dipartimento di Biologia Animale Piazza Botta 1027100 Pavia, Italy E-mail:marcobig@unipv.it 